\title{
Emergency thoracotomy for massive hemothorax
}

\author{
Toracotomia de emergência para solução de hemotórax maciço
}

\section{Eduardo Santiago Ventura de Aguiar ${ }^{1}$, Alessandra Quaresma Ferreira ${ }^{2}$, Ida Quaresma Ferreira ${ }^{2}$, Suzane Lílian Beier ${ }^{1} \&$ Marcelo Borba ${ }^{1}$}

\begin{abstract}
A tree year old female Cocker Spaniel was admitted, hitted by a car. The patient presented progressive hypotension, epistaxis, fast and weak pulse, capillary refill time (CRT) of 4 seconds and progressive dispnea. An infusion with lactated ringer $(90 \mathrm{ml} / \mathrm{kg} / \mathrm{h} \mathrm{IV})$ and oxygen therapy were started. The thoracocentesis revealed massive hemopneumothorax in both sides of the chest, and one thoracic drain was inserted in each hemithorax. Peripherical pulse became untouchable indicating severe blood pressure fall, and the patient got unconscious. In this way, was decided to perform an emergency thoracotomy by a transesternal resection on the fifth intercostal space, and a pulmonary lobectomy was than executed. The patient had a good recovery and at this moment she is healthy.
\end{abstract}

Key words: dog, hemorrhagic shock, transesternal thoracotomy.

\section{RESUMO}

Foi admitida uma cadela Cocker Spaniel, com 3 anos de idade e $12 \mathrm{~kg}$, vítima de atropelamento. A paciente apresentava hipotensão progressiva, epistaxe, pulso fraco e rápido, tempo de perfusão capilar de 4 segundos, dispnéia progressiva. Iniciou-se a infusão com solução de ringer com lactado de sódio ( $90 \mathrm{ml} / \mathrm{kg} / \mathrm{h} \mathrm{IV})$ e oxigenoterapia. A toracocentese indicou hemopneumotórax maciço, sendo inserido um dreno torácico em cada hemitórax. O pulso periférico tornou-se não palpável, denotando queda grave na pressão arterial, levando a paciente à inconsciência. De imediato, optou-se pela realização da toracotomia de emergência, com acesso transesternal pelo $5^{\circ}$ espaço intercostal, aonde foi realizada a lobectomia pulmonar. A paciente recuperou-se e, no presente momento, passa bem.

Descritores: cão, choque hemorrágico, toracotomia transesternal. 


\section{INTRODUCTION}

Trauma is one of the largest causes of death in small animals [9]. Such lesions can lead to hemorrhage, with high incidence in small animal practice [1,4-6,8,9]. Thoracic injuries in particular account for approximately $25 \%$ of trauma associated deaths. Although the majority of hemodynamically stable patients with thoracic injuries can initially be managed with tube thoracostomy in both sides of the chest and close observation, some patients may progress to develop acute complications requiring operative therapy. Experience in veterinary emer-gency and critical care has shown that many deaths would be avoided by organized conducts [7,9]. The emergency thoracotomy seems to be an alternative to control a massive bleeding, in order to localize and solve the lesion. In such procedure, there is no time to reach the operating theatre and undertake asepsis of the

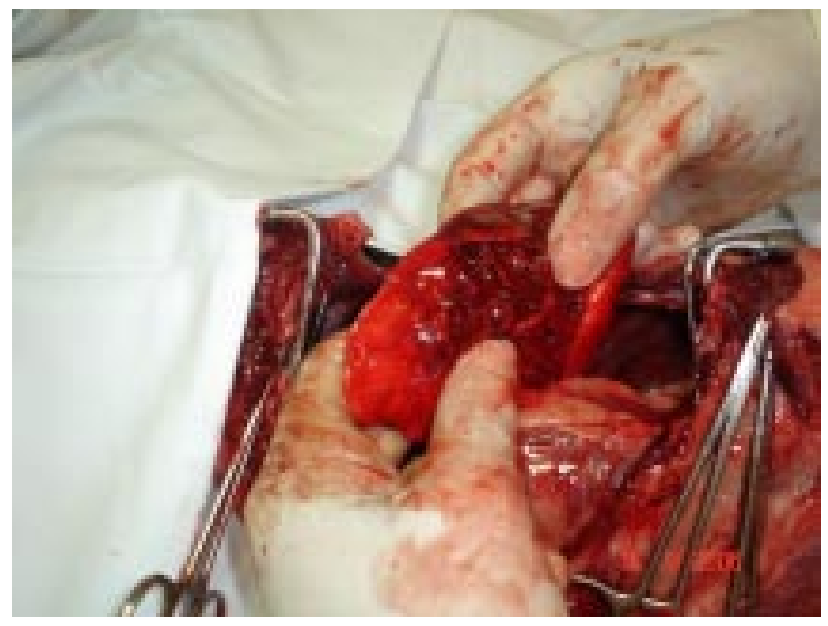

Figure 1. Large tear located on the left caudal lung, on its visceral face.

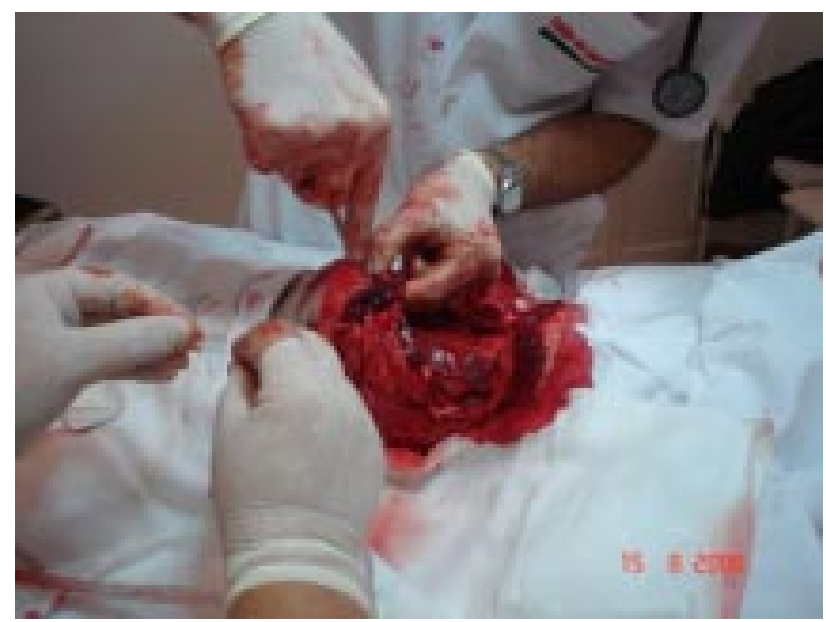

Figure 3. Orthopedic steel wire applied for sternum closure. area in the same way as a planned operation. The main objective is to keep the life of the patient. However, in those cases where death is almost a certainty, the risk of infection is no longer important $[1,2,4-6]$.

\section{CASE REPORT}

A tree year old female Cocker Spaniel was admitted by car accident 50 minutes ago. The patient presented progressive hypotension, depression, epistaxis, fast and weak pulse, CRT of 4 seconds and progressive dispnea. The therapy against the hemorrhagic shock was started with lactated ringer $(90 \mathrm{ml} /$ $\mathrm{kg} / \mathrm{h}$ IV) and oxygen by facial mask. The abdominocentesis revealed a negative result, on the contrary, the thoracocentesis was positive for air and blood in both sides of the thorax. Due to this result, one thoracic drain was inserted in each hemithorax. The blood

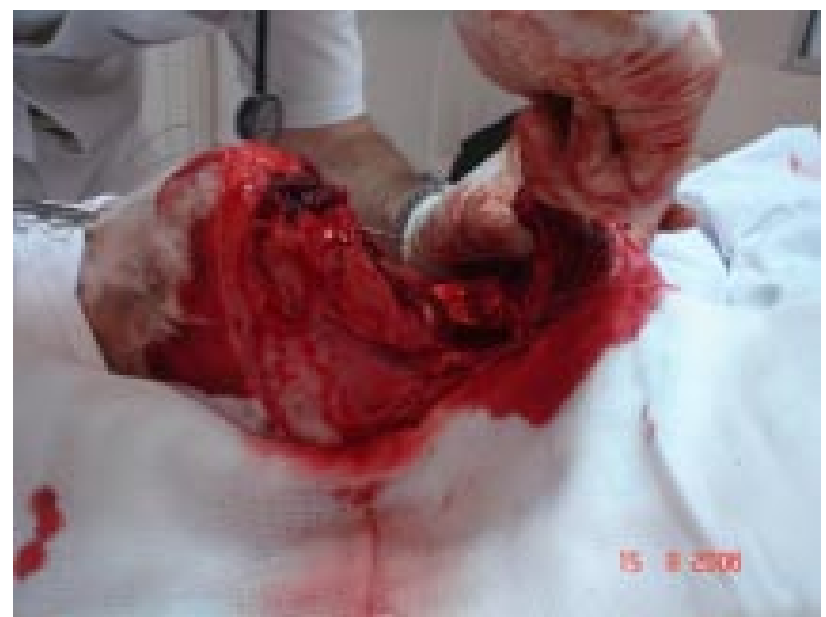

Figure 2. Aspect of the surgical theatre on the emergency room, where the cares about ani-sepsia and assepsia can not be taken.

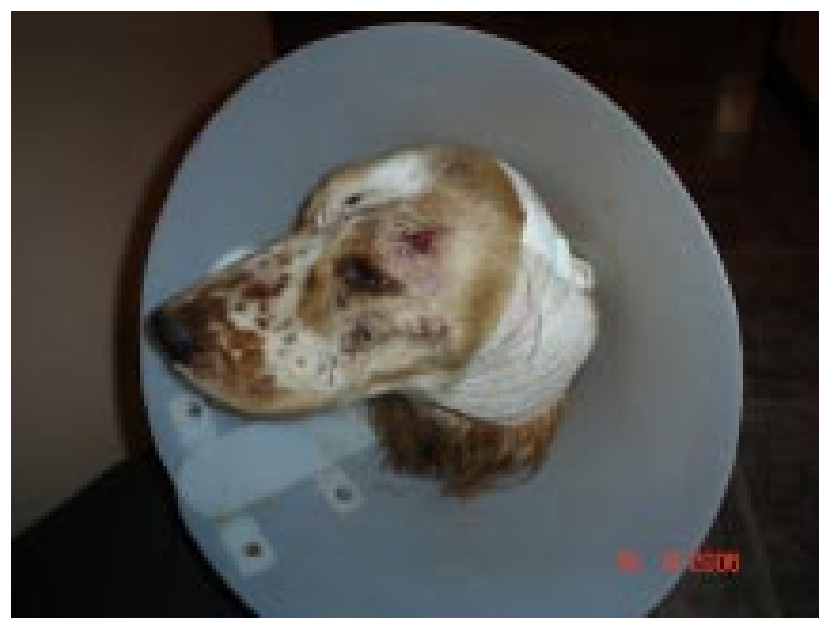

Figure 4. Aspect of the patient 24 hours after surgery. 
pressure dropped until the peripherical pulse was no longer felt, and the patient got unconscious. In this way, was decided to perform an emergency thoracotomy by a transesternal resection on the $5^{\text {th }}$ intercostal space, and the aorta was cross-clamped. A pulmonary tear was located, in the left caudal lobe (Figure 1). The pulmonary lobectomy was than performed with the three clamps technique, where the pulmonary vessels and bronchius lobe were ligated with nylon 3-0. The cavity was irrigated with warm saline several times and the aorta was declamped after eight minutes. No hemorrhage was detected after the declamping. The thoracorraphy started by the sternum, with an orthopedic steel wire 2-0 (Figure 2 and $3)$. The intercostal spaces were approximated with nylon $2-0$, in a continuous suture around the $5^{\text {th }}$ and $6^{\text {th }}$ ribs. The muscle layers were sutured with nylon $2-0$, in a continuous fashion, and the same pattern and suture material was employed on the skin. The post-operatory therapy consisted in progressive warming, enrofloxacin ( $5 \mathrm{mg} / \mathrm{kg}$ BID PO) associated with metronidazole ( $8 \mathrm{mg} / \mathrm{kg}$ TID IV), and analgesia with morphine sulfate $(1,0 \mathrm{mg} / \mathrm{kg}$ QID IM). The surgical wounds were cleaned up twice a day, with gauze and saline (Figure 4). The drains were kept by five days for effusion and air drainage. The patient had a good recovery and at this moment she is healthy.

\section{DISCUSSION}

The transternal access allowed the visualization of all thoracic organs, including the vessels of the base of heart and lungs, with easily rib retraction. The manual retraction is initially necessary, but latter the abdominal wall muscles naturally contributes to thoracic deviation. Despite this is not a very common procedure in Veterinary Medicine, it gave a better access of all cavity and its exploration in search of lesions [1]. Infection is no longer a concern, because of the iminent death by hemorrhage and respiratory failure. In this way, the cares about anti-sepsia and asepsia are not taken. If the patient gets an infection, it means the he is alive [1]. The irrigation of the cavity concur to diminish the contami-nation so antimicrobials can control the infection in a easier way. Thoracic drains were of extreme relevancy, helping not only breathing and venous return, but to exsudate drainage after a contamined procedure [2].

Aortic crossclamping maneuver helped to stop the blood loss, and also to find the sites of bleeding. It last for eight minutes, according to the recommended of ten minutes, with two minutes of declamping. In this case report, only one period of aortic crossclamping was necessary [1,3-6].

The organized conducts which were adopted in this case report, like the transternal resection, aortic crossclamping and the manteinance of a well trained staff concurred for success [7]. In this way, the authors recommend the transternal resection by its rapid and easily thorax access and fast closure, and the aortic crossclamping, which promoted the faster hemostasia and the return to the physiological hemodynamics levels, and to the patient survival.

\section{REFERÊNCIAS}

1 Aguiar E.S.V. 2006. Emergências decorrentes do trauma em pequenos animais: técnicas e manual para equipes de prontoatendimento. 347f. Santa Maria, RS. Tese (Doutorado em Medicina Veterinária) - Programa de Pós-graduação em Medicina Veterinária, Universidade Federal de Santa Maria.

2 Corral E., Silva J., Suárez R.M., Nuñez J. \& Cuesta C. 2007. A successful emergency thoracotomy performed in the field. Resuscitation. $75: 530-533$.

3 Crowe D.T. \& Rabelo R.C. 2005. Ressuscitação Cárdio-Cérebro-Pulmonar (RCCP). In: Crowe D.T. \& Rabelo R.C. (Eds). Fundamentos de Terapia Intensiva Veterinária em Pequenos Animais. Rio de Janeiro: LF Livros de Veterinária LTDA., pp. 683-694.

4 Hauptman J. \& Chaudry I.H. 1998. Choque. In: Bojrab M.J. (Ed). Mecanismos da Moléstia na Cirurgia dos Pequenos Animais. 2.ed. São Paulo: Manole, pp.21-25.

5 Klainbart S., Mazaki-Tovi M., Auerbach N., Aizenberg I., Bruchim Y., Dank G., Lavy E., Aroch I. \& Harrus S. 2007. Spirocercosis-associated pyothorax in dogs. Veterinary Journal. 173: 211-216.

6 Manlulu A.V., Lee T.W., Thung K.H., Wong R. \& Yim A.P.C. 2004 Current indications and results of VATS in the evaluation and management of hemodynamically stable thoracic injuries. European Journal of Cardio-Thoracic Surgery. 25: 1048-1053. 
7 Rabelo R.C. 2007. Importância do treinamento de pessoal médico e não-médico no preparo de um sistema de drenagem torácico na sala de emergência. Acta Scientiae Veterinariae. 35: 694-695.

8 Westphal F.L., Lima L.C. \& Fadul M.A.T. 1998. Lesão da artéria torácica interna por dreno torácico: relato de caso. Jornal de Pneumologia. 24: 382-384.

9 Wingfield W.E. 1998. Parada Cardiopulmonar e Ressuscitação em Pequenos Animais. In: Wingfield W.E. (Ed). Segredos em Medicina Veterinária. Porto Alegre: Artes Médicas Sul, pp.23-36. 